DOI: https://doi.org/10.32839/2304-5809/2020-4-80-48

UDC 621.311

Samoilyk Oleksandr, Tkachenko Valentyn, Kurbaka Halyna

Cherkasy State Technological University

\title{
RESEARCH OF THE EFFECT OF ACCUMULATOR-BASED ENERGY STORAGE DEVICESON THE EFFICIENCY OF USING VIRTUAL POWER PLANTTECHNOLOGIES
}

Summary. The effect of accumulator-based energy storage devices on the efficiency of using virtual power plant (VPP) technologies at the stage of optimization of network topology of the newly created VPP is investigated. Such an integration involves not only solidary covering of its own load due to the organization of additional transmission lines, but also the transfer of excess electricity to the system. The algorithm of structural properties estimation on the example of a virtual power plant formed by three electrotechnical complexes is considered. One of the possible optimization scenarios by means of structural analysis of systems is suggested as a tool. As a criterion that allows to evaluate the correct choice of a particular topology of the electrical network, it is proposed to use the amount of "released" power. The main attention is focused on the problem of optimal redistribution of accumulated energy, that is, essentially, the rationalization of the "charge - discharge" cycle of accumulator systems. The relations representing the mathematical model of the electrotechnical complex with the use of distributed generation sources and electrical energy storage devices in the form of accumulator systems are obtained. Herewith the completeness of solutions depends on specific characteristics of the components of the virtual power plant.

Keywords: accumulator systems, virtual power plants, "released" power, energy, electrotechnical complexes, mathematical model.

Самойлик О.В., Ткаченко В.Ф., Курбака Г.В.

Черкаський державний технологічний університет

\section{ДОСЛІДЖЕННЯ ВПЛИВУ НАКОПИЧУВАЧІВ ЕНЕРГІЇ НА БАЗІ АКУМУЛЯТОРНИХ СИСТЕМ НА ЕФЕКТИВНІСТЬ ВИКОРИСТАННЯ ТЕХНОЛОГІЙ «ВІРТУАЛЬНИХ ЕЛЕКТРОСТАНЦІЙ»}

Анотація. В роботі досліджено вплив накопичувачів енергії на базі акумуляторних систем на ефективність використання технологій «віртуальних електростанщій» (Virtual Power Plant - VPP) на eтапі оптимізації топології мережі новоствореної VPP. Як об’ект розглянуто об’єднання декількох незалежних, територіально рознесених окремих електротехнічних комплексів з власними споживачами в единий комплекс, що функціонуе за технологією «віртуальної електростанції». Таке об’еднання передбачає не тільки солідарне покриття власного навантаження за рахунок організації додаткових ліній електропередачі, а й передачу надлишкової електроенергії в систему. Розглянуто основні обмеження і параметри передбачуваних приеднань, що підлягають оптимізащії. Оскільки повнота і якість отриманих при об'єднанні у VPP переваг великою мірою визначаються додатковими варіантами топології новоствореної мережі, розглянуто алгоритм оцінювання структурних властивостей на прикладі віртуальної електростанції, утвореної трьома електротехнічними комплексами. Як інструмент запропоновано один із можливих сценаріїв оптимізації за допомогою структурного аналізу систем. Оскільки ідеологія формування «віртуальної електростанції» з існуючих комплексів спрямована на підвищення ефективності електропостачання за рахунок максимального використання всього потенціалу розподіленої генерації, як критерій, що дає змогу оцінити правильність вибору тієї чи іншої топології електричної мережі, запропоновано використовувати величину «вивільненої» потужності. Основну увагу сконцентровано на проблемі оптимального перерозподілу енергії, що акумулюеться, тобто, по суті, на раціоналізації циклу «заряд - розряд» акумуляторних систем. Отримано співвідношення, що представляють математичну модель електротехнічного комплексу 3 використанням джерел розподіленої генерації та накопичувачів електроенергії у вигляді акумуляторних батарей. Рішення задачі моделювання передбачає реалізащію послідовності математичних розрахунків відповідно до розробленої методики. При цьому повнота рішень залежить від конкретних характеристик складових віртуальної електростанції.

Ключові слова: акумуляторні системи, віртуальні електростанції, «вивільнена» потужність, енергія, електротехнічні комплекси, математична модель.

\section{The problem under introduction of}

discussion. Active small distributed generation (DG), including one based on renewable energy sources (RES) is one of the directions of modernization of domestic electrical power industry [1]. Virtual power plant (VPP) technologies can be used to increase the efficiency of such facilities. The term "virtual power plant" will hereinafter mean the integration of separately located electrotechnical complexes (ETCs) on the basis of distributed generation based on renewable energy sources to function as a single imaginary power plant. Thus,
VPP is a community of distributed generators, energy storage devices (usually accumulator systems) and controlled loads which are connected by informationcommand interfaces located in switchgear (SG) of individual electrotechnical complexes. The VPP thus formed is capable of fully performing the functions of planning, coordinating the flow of electricity both between VPP facilities and with the external power system. The virtual power plant actually integrates technical and technological solutions to manage the demand and supply of distributed energy generation using software and hardware. 
Analysis of recent research and publications. In this direction, in [2] the definitions have been reviewed, the VPP components have been indicated, and the existing restrictions have been pointed out. The authors [3] have discussed general issues of increasing the efficiency of network power through VPP technologies. Business-level and management-level measures for VPP organization have been analyzed. In [4], systems of remote control and synchronization of complex measurements in virtual power networks have been described, the basic parameters and characteristics of electromagnetic compatibility have been determined.

The peculiarities of construction and functioning of virtual power plants and their impact on the operation of the unified power system of Ukraine have been analyzed by the authors [5]. VPP structural units and variants of their joint work have been presented, electricity quality problems caused by the availability of renewable and unconventional energy sources have been considered.

Highlighting of previously unresolved parts of a common problem. Currently, VPP technologies are being researched by scientists from all developed countries. As a rule, the most attention is paid to management systems and mechanisms of sale (purchase) of electricity. However, it is equally important to solve technical and technological issues of combining several DGs into a single electrical network, in particular, the problem of choosing the optimal topology of such electrical network and investigating the impact of individual factors on the efficiency of such an integration. It depends, in particular, whether virtual power plants will be significant in the achievable perspective.

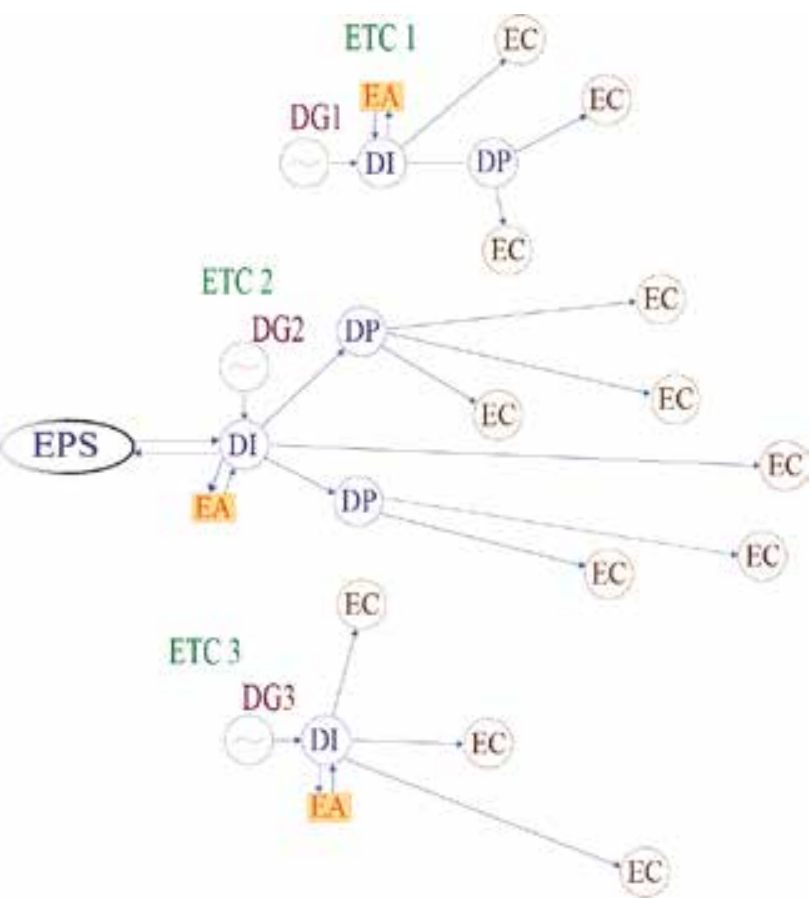

Figure 1. A group of independent ETCs:

EPS - electrical power system; EC - electricity consumer; DG - distributed generation;

ETC- electrotechnical complex; DI - distribution installation; EA - energy accumulator; DP - distribution point
The aim of the article is to investigate the effect of accumulator-based energy storage devices on the efficiency of virtual power plant technologies.

Outline of the main research material. Combining several independent, territorially separated ETCs with their own consumers (Fig. 1) into a single complex operating on VPP technology (Fig. 2) provides solidary coverage of the load due to the organization of additional transmission lines (TL).

The locations of transmission lines and their characteristics are unknown and are subject to further definition.

Thus, a virtual power plant, which is formed by separately located electrotechnical complexes on the basis of distributed generation based on RES with energy storage devices, is the object of further research.

Selection of initial electrotechnical complexes with the structure shown in Figure 1 as VPP a priori provides for the need of DG sources operation for maximum power output, regardless of the load level of both individual consumers and the total load. The positive effect consists:

- for owners of individual ETCs - in the possibility of selling the excess power (energy);

- for consumers - in expanding the ability to cover the load schedule, including at the expense of VPP electricity at lower prices.

Let's consider the main limitations and parameters of the predicted connections to be optimized.

The ratio between operating current $I_{i j}$ in normal mode and allowable current continued $I_{i j \text { allow.c }}$ for a given power line is the first obvious limitation [6]:

$$
I_{i j} \leq I_{i j \text { allow.c. }} \text {. }
$$

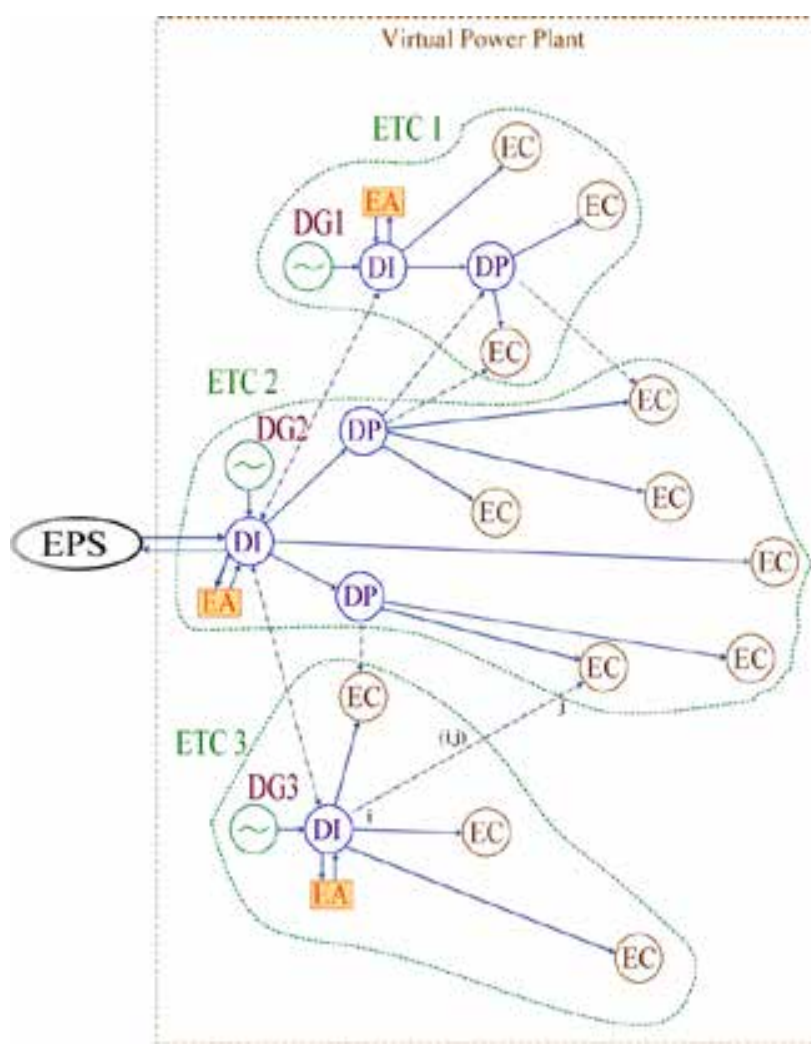

Figure 2. Virtual power plant based on individual electrotechnical complexes - dotted line indicates potential connections 
In this case, the passage of operating current of the supply line should not cause a voltage drop below the allowable [6]:

$\Delta U_{i j}=\sqrt{3} \cdot I_{i j} \cdot L_{i j} \cdot\left(r_{o i j} \cdot \cos \varphi_{i j}+x_{o i j} \cdot \sin \varphi_{i j}\right) \leq 0,1 \cdot U_{N O M},(2)$

where $L_{i j}$ is the length of $(\mathbf{i}, \mathbf{j})$-th connection; $r_{o i j}$, $x_{o i j}$ are respectively active and reactive resistance of the $(\mathbf{i}, \mathbf{j})$-th power line; the angle $\varphi_{i j}$ characterizes the phase shift between current and voltage in the line $(\mathbf{i}, \mathbf{j})$.

The number of newly created lines between existing ETCs (Figure 2) and their technical and economic characteristics are subject to optimization.

For example:

- a provision of the necessary class of security of energy supply;

$-\mathrm{a}$ sale of surpluses to the external power system;

- an obtaining of additional flexible power;

- an opportunity to participate fully in the market as a producer;

- a new level of work with consumers, an opportunity to offer new consumer management programs;

- other urgent and relevant goals can serve as such characteristics, depending on the main purposes of consumers integration into a virtual power plant.

The tasks set out should be coordinated accordingly.

The completeness and quality of the benefits of VPPs integration are largely determined by additional variants of the topology of the newly created network.

Let's consider one of possible algorithms for estimating structural properties on the example of a virtual power plant formed by three ETCs (Figure 1). As a tool we use structural analysis of systems [7].

Formalization of the structure description is based on graph theory.

We have used the most visual form of a formalized graph task - graphical representation - to represent the relationships between the elements in Figure 2.

Individual ETCs (in Figure 2 ETC 1 - ETC 3) formally represent subsystems, and individual objects (switchgears and switchgear points, consumers, etc.) that form them are elements of the system.

The graph presented here is oriented, since it consists only of oriented edges. The orientation corresponds to preferred directions of power transmission in the network. The elements of the system - switchgears, switchgear points, distributed generators, accumulators of energy and electricity consumers - are vertices of the graph. Vertices (nodes) of the graph correspond to the values of electrical power, capacity and consumption (load).

Transmission lines serve as branches of the graphs. They are characterized by the direction of power transmission, length, values of specific active and reactive resistances, selected technical and economic indicators.

Potentially feasible variants of electrical connections in Figure 2 are shown by dotted lines.

For further analysis it is convenient to represent the graph in numerical form, namely in the form of a matrix.
Presented in Figure 2, the graph of a virtual power plant is described using vertices adjacency matrix:

$$
A=\left\|a_{i j}\right\|_{m}^{n}, i=\overline{1, n} ; j=\overline{1, m},
$$

where $a_{i j}$ is the element of the matrix $\mathbf{A} ; \mathrm{n}$ is the number of nodes of the graph; $\mathrm{m}$ is the number of branches (arcs) of the graph.

Elements of adjacency matrix $a_{i j}$ of vertices A for oriented graph are defined as follows [8]:

$a_{i j}=\left\{\begin{array}{l}1, \text { if there is a connection (if you can go from vertex i to vertex } j ; \\ 0, \text { if there is no connection }\end{array}\right.$

The type of adjacency matrix of oriented graphs depends essentially on the chosen order of vertices numbering and, by selecting a certain principle of vertices numbering for some types of graphs (without contours), it is possible to reduce the matrix A to a triangular form, where $a_{i j}=0$ for $j>i$.

Adjacency matrix of vertices $\mathbf{A}$ is a matrix of direct graph paths having a length equal to 1 . The total number of transit paths from vertex $\mathbf{i}$ to $\mathbf{j}$ with the length $\mathbf{k}$ can be obtained by reducing the matrix $\mathbf{A}$ to the degree $\mathbf{k}$.

Structural properties of electrical network of a virtual power plant can be determined on the basis of structural-topological characteristics of the graph, which are calculated using vertices adjacency matrix.

When conducting structural analysis of systems, it is often necessary to identify some of structural characteristics of systems and to quantify them. The expediency of determining such parameters is that already at an early stage of design there is a need to evaluate the quality of the structure of the system and its elements from the standpoint of system approach.

The main of these characteristics are given below.

Connectivity of structure. This quantitative parameter allows to detect the presence of breaks in the structure, hanging vertices, etc.

Most fully, quantitatively, the connectivity of elements of the oriented graph is determined by connectivity matrix $C=\left\|c_{i j}\right\|$.

The greater the value $\boldsymbol{C}$, the higher the value of connectivity is and the potentially more reliable the considered network topology is. For an oriented graph, it can be determined by the expression:

$$
C=\sum_{i=1}^{n} \sum_{j=1}^{n} c_{i j},
$$

where $n$ is the number of nodes of the graph, $c_{i j}$ is the element of connectivity matrix $\mathbf{C}$, which is determined by the relation:

$$
c_{i j}=\left\{\begin{array}{ll}
1, & \text { if } a_{i j}^{\Sigma} \geq 1 \\
0, & \text { if } a_{i j}^{\Sigma}=0
\end{array},\right.
$$

where $a_{i j}^{\Sigma}$ is the element of the total adjacency matrix $A_{\Sigma}$ that determines the total number of paths from node $\mathbf{i}$ to node $\mathbf{j}$.

The matrix $A_{\Sigma}$ can be defined as follows:

$$
A_{\Sigma}=\sum_{k=1}^{n} A^{k},
$$

where $\mathbf{A}$ is adjacency matrix of graph vertices; $\mathbf{k}$ is the length of the path (number of sections) from vertex $\mathbf{i}$ to vertex $\mathbf{j}$.

Structural redundancy. A structural parameter that reflects the excess of the total number of con- 
nections over the minimum required one is called structural redundancy $\mathrm{R}$, which is defined as follows:

$$
R=\left[\sum_{i=1}^{n} \sum_{j=1}^{n} a_{i j}\right] \cdot \frac{1}{n-1}-1, i \neq j,
$$

where $a_{i j}$ is the element of adjacency matrix of vertices $\mathbf{A} ; n$ is the number of graph vertices.

The most economical topology should have a minimum number of redundant electrical connections, the presence of which will increase the cost on building of additional power lines, necessary switching and protective equipment. Thus, the topology with the lowest characteristic value should be considered as the best one.

Uneven distribution of connections - a parameter that characterizes the underutilization of capabilities of a given topology in achieving the maximum connectivity. It is taken into account by the indicator - quadratic deviation of the given distribution of vertices degree. It is determined by the expression:

$$
\varepsilon^{2}=\sum_{i=1}^{n}\left(\rho_{i}^{2}-\frac{4 m^{2}}{n}\right),
$$

where $\rho_{i}$ is the true degree of the $\mathbf{i}$-th vertex of the graph (the number of edges incident to the $\mathbf{i}$-th vertex of the graph); $\mathrm{m}$ is the number of edges of the graph; $\mathrm{n}$ is the number of vertices of the graph.

A parameter value, equal to zero, characterizes a uniform topology.

The greater the magnitude $\varepsilon^{2}$, the greater the unevenness of connections is. Thus, the topology with the smallest parameter value will be considered as the best one.

Structural compactness. To quantify structural compactness, a parameter is introduced that reflects the proximity of elements to each other. The proximity of two elements $\mathbf{i}$ and $\mathbf{j}$ will be determined by the minimum path length for oriented graph (chain - for non-oriented one) $d_{i j}$. Then the value $Q$ reflects the overall structural proximity of elements to each other in the system:

$$
Q=\sum_{i=1}^{n} \sum_{j=1}^{n} d_{i j}, i \neq j
$$

where $d_{i j}$ is the minimum path length from vertex $\mathbf{i}$ to vertex $\mathbf{j}$; $\mathrm{n}$ is the number of vertices of the graph.

To quantify structural compactness, often use a relative index:

$$
Q_{R E L}=Q / Q_{C G}^{1},
$$

where $Q_{C G}^{1}=n(n-1)$ is the value of compactness for the structure of a system of "complete graph" type.

Structural compactness can be characterized by another indicator - the structure diameter:

$$
d=\max _{i j} d_{i j} \text {. }
$$

The degree of centralization in the structure. The concept of centrality index is used to quantify the degree of centralization in a structure:

$$
\delta=(n-1) \frac{2 Z_{\text {max }}-n}{Z_{\text {max }}(n-2)},
$$

where $\mathrm{n}$ is the number of vertices of the graph.

The component of this formula can be found as follows:

$$
Z_{\text {max }}=\max \left\{Z_{i}\right\},
$$

where $Z_{i}$ is the value determined according to the following expression:

$$
Z_{i}=\frac{Q}{2}\left(\sum_{j=1}^{n} d_{i j}\right), i=\overline{1, n} ; i \neq j,
$$

where $\mathrm{Q}$ is structural compactness of the topology; $d_{i j}$ is the minimum length of the path vertex $\mathbf{i}$ to vertex $\mathbf{j} ; \mathrm{n}$ is the number of vertices of the graph.

The smaller the parameter value, the more reliable the topology is. High value of the degree of centralization imposes increased requirements for the capacity of central element in the network topology, through which a large number of connections are established, as well as for the reliability of its functioning, since the failure of this element leads to disruption of normal operation of the entire system. With a large parameter value, it makes sense to duplicate central element in order to improve the reliability of the topology. A network topology with a smaller parameter value is better.

Assessment and further comparison of variants of network topology separately for each structural and topological characteristic are usually a rather trivial task.

However, the choice of the optimal network topology, taking into account the whole set of parameters considered, that is, solving a multicriteria problem, presents some difficulties. Taking into account the impact of individual factors (such as availability, performance, and mode limitations of energy accumulators) adds additional features to the multifactorial problem.

Currently, there are quite a number of methods for solving multicriteria problems [7]. A multicriteria problem is often reduced to a single-criterion one. This approach involves the use of supercriterion as a scalar function of a vector argument:

$$
q_{0}(x)=q_{0}\left(q_{1}(x), q_{2}(x), \ldots, q_{p}(x)\right),
$$

where $q_{1}(x), q_{2}(x), \ldots, q_{p}(x)$ are the criteria; $x$ is the alternative of the set $X$.

The type of the function $q_{0}$ depends on the contribution of each criterion to the overall supercriterion. As a rule, in this case, additive and multiplicative functions of the following form are used:

$$
\begin{gathered}
q_{0}=\sum_{i=1}^{p} \alpha_{i} q_{i} ; \\
1-q_{0}=\prod_{i=1}^{p}\left(1-\beta_{i} q_{i}\right),
\end{gathered}
$$

where $\alpha_{i}$ and $\beta_{i}$ are weighting factors.

The main difficulty of this method consists in the determination of weighting factors $\alpha_{i}$ or $\beta_{i}$.

The whole ideology of forming a "virtual power plant" from existing ETCs is aimed at improving the efficiency of electricity supply by maximizing the use of all the potential of distributed generation.

It is logical that the value of "released" power can be used as a criterion to evaluate the correct choice of a particular electrical network topology.

By "released" power we mean the power of power sources, which, after combining the ETCs, can be both usefully used in the same electrical network and transmitted to the power system.

Thus, the function $\Upsilon\left(P_{E P S_{\Sigma}}\right)$ characterizing the "released" power in the VPP for transmission to the power system is subject to optimization:

$$
\Upsilon\left(P_{E P S . \Sigma}\right) \rightarrow \max \text {. }
$$


Among other problems associated with the implementation of VPP technologies, not only the optimization of newly formed connections but also the identification of an internal reserve in ETC due to, for example, optimal redistribution of accumulated energy, i.e. essentially the rationalization of the "charge - discharge" cycle of accumulator systems, is of great interest. This aspect is discussed below.

Let's carry out the analysis of power for individual electrotechnical complex, the structure of which is presented in Figure 1.

Let's consider the balance of power in the ETC in the mode of accumulator charging and transferring the excess energy to the power system (Figure 3).

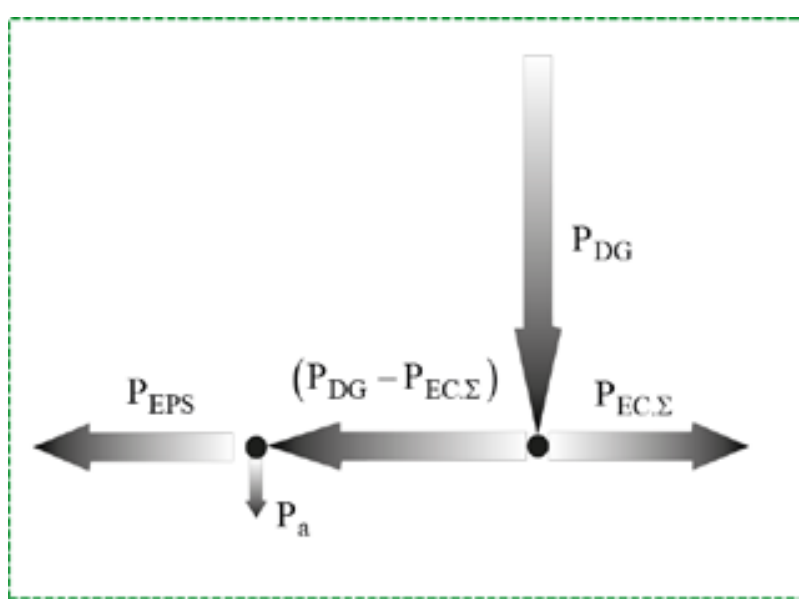

Figure 3. Power balance in the system of autonomous power supply of an enterprise in the mode of accumulator charging and transferring the excess energy to electric power system ( $P_{E P S}-$ excess power that can be transferred to the EPC) form:

In analytical form, the specified balance has the

$$
P_{D G}+P_{a} \geq P_{E C . \Sigma} \cdot k_{s},
$$

where $P_{D G}$ is the power generated by distributed generation sources, $\mathrm{W} ; P_{a}$ is the power accumulated, W; $P_{E C . \Sigma}$ is the power required for electricity consumers, W; $k_{S}$ is the factor of stock.

The system of electricity accumulation, depending on quantitative ratio of produced and consumed energy, can act as both its source and the receiver. Accordingly, in practice the following variants of motion of energy flows that determine the power balance in a given electrotechnical complex are possible:

1. Electricity power $P_{D G}$ generated at any given time $(t)$ from the considered time interval $(T)$, taking into account losses, exceeds the power $P_{E C . \Sigma}$ that consumers need.

The amount of energy that can be stored at the current time $(t)$ is determined by two parameters: the "free" capacity of accumulation system $\left(\Theta_{a}\right)$ and the maximum value of charge current $I_{c h}$. If the value of accumulated capacity is $C_{a}$, then

$$
C_{a} \cdot\left(1-k_{d}\right) \geq \Theta_{a},
$$

where $k_{d}$ is the allowable accumulator discharge ratio (usually $k_{d} \approx 0,2$ ).

Thus, mathematical expression for calculating the power balance at $P_{a}=P_{D G}-\frac{P_{E C . \Sigma}}{\chi} \geq 0$ in accordance with Figure 2 will look like:

$$
\begin{array}{ll}
\left\{\begin{array}{l}
P_{a} \cdot t \leq \Theta_{a} \cdot U_{a} \cdot k_{a} ; \\
I_{a}=\frac{P_{a}}{N_{a} \cdot U_{a}} \leq I_{c h},
\end{array}\right. & \Rightarrow\left\{\begin{array}{l}
\Theta_{a}^{e n}=\Theta_{a}-\frac{P_{a} \cdot t}{U_{a}} \eta ; \\
P_{E P S}=0
\end{array}\right. \\
\left\{\begin{array}{l}
P_{a} \cdot t \leq \Theta_{a} \cdot U_{a} \cdot \eta ; \\
I_{a}=\frac{P_{a}}{N_{a} \cdot U_{a}}>I_{c h},
\end{array}\right. & \Rightarrow\left\{\begin{array}{l}
\Theta_{a}^{e n}=\Theta_{a}-I_{c h} \cdot t \cdot \eta ; \\
P_{E P S}=P_{a}-I_{c h} \cdot U_{a}
\end{array}\right. \\
\left\{\begin{array}{l}
P_{a} \cdot t \geq \Theta_{a} \cdot U_{a} \cdot \eta ; \\
I_{a}=\frac{P_{a}}{N_{a} \cdot U_{a}} \leq I_{c h},
\end{array}\right. \\
\left\{\begin{array}{l}
P_{a} \cdot t \geq \Theta_{a} \cdot U_{a} \cdot \eta ; \\
I_{a}=\frac{P_{a}}{N_{a} \cdot U_{a}}>I_{c h},
\end{array}\right.
\end{array}
$$

where $N_{a}$ is the number of accumulators connected in parallel; $U_{a}$ is charge voltage of one accumulator, $\mathrm{V} ; I_{c h}$ is charge current of one accumulator, $\mathrm{A} ; \eta<1$ is accumulator efficiency; $\Theta_{a}$ and $\Theta_{a}^{e n}$ are initial and final values of the "free" capacity of accumulation system, $A$ - hours ; $P_{a}$ is excess power, some of which can be accumulated or transmitted to power system, W; $\chi<1$ is the efficiency of the inverter as a part of $\mathrm{SG}$.

2. The power of electricity $\left(P_{D G}\right)$ generated at any given time $(t)$ from the considered time interval $(T)$, taking into account the losses, is less than the power $P_{E C . \Sigma}$ required for consumers of ETC. The power shortage should be filled, if possible, from electricity storage system.

Power balance at $P_{a}=P_{D G}-\frac{P_{C \Pi . \Sigma}}{\chi}<0$ is described
follows: as follows:

$\left\{\begin{array}{l}\left|P_{a}\right| \cdot t \leq\left[\left(1-k_{d}\right) \cdot C_{a}-\Theta_{a}\right] \cdot U_{a} ; \\ I_{a}=\frac{\left|P_{a}\right|}{N_{a} \cdot U_{a}} \leq I_{d},\end{array} \Rightarrow\left\{\begin{array}{l}\Theta_{a}^{e n}=\Theta_{a}+\frac{\left|P_{a}\right| \cdot t}{U_{a}} \Psi_{p}\left(I_{a}\right) ; \\ \bar{C}_{a}=\left(1-k_{d}\right) \cdot C_{a}-\Theta_{a}^{e n}>0\end{array}\right.\right.$

where $I_{d}$ is the maximum allowable current of accumulator discharge, $\mathrm{A} ; \Psi_{p}\left(I_{a}\right)$ is some corrective function of discharge current in the circuit of accumulation system, the value of which $\geq 1 ; \bar{C}_{a}$ is current accumulator capacity, $A$ - hours .

Values of parameters $I_{d}$ and $\bar{C}_{a}$ determine the efficiency of electrotechnical complex.

The capacity of accumulation system, the rate of accumulation (charge) and parameters of the return of electricity (discharge) are the most important characteristics. The latter, on the one hand, are limited by the maximum permissible values of charge $\left(I_{c h}\right)$ and discharge $\left(I_{d}\right)$ currents, on the other - by the dependence of the value of real capacity of some of accumulation systems on the magnitude of discharge current.

The total power (4) is in general a function of time, the values of which are available at discrete points $t_{i}$ given at constant time intervals:

$$
\Delta T=t_{i+1}-t_{i}=\text { const } .
$$

Then, considering that the function $P_{D G}(t)$ over a period of time $\Delta T$ varies linearly from value $P_{1}$ to $P_{2}$, and power consumption $P_{E C . \Sigma}$ is constant, we will have the following expressions to calculate the excess $W_{e x}$ and absent $W_{m}$ energy in the following four possible variants of relations between values $P_{1}, P_{2}$ and $P_{E C . \Sigma}$ : 


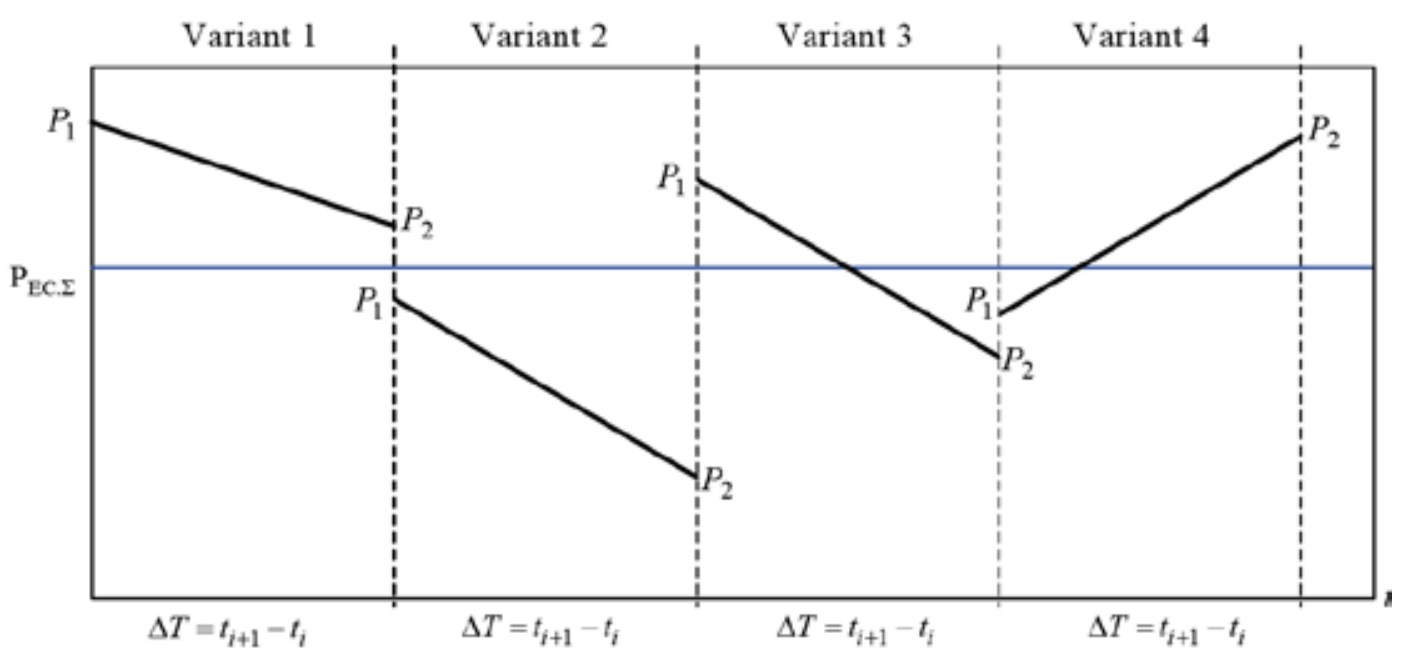

Figure 4. Possible variants of relations between values $P_{1}, P_{2}$ and $P_{E C . \Sigma}$

1) $P_{1} \geq \frac{P_{E C . \Sigma}}{\gamma}, P_{2} \geq \frac{P_{E C . \Sigma}}{\gamma},\left\{\begin{array}{l}W_{e x}=\frac{P_{1}+P_{2}-\frac{2 P_{E C . \Sigma}}{\chi}}{2} \cdot \Delta T ; \\ W_{m}=0\end{array}\right.$

2) $P_{1}<\frac{P_{E C . \Sigma}}{\chi}, P_{2}<\frac{P_{E C . \Sigma}}{\chi},\left\{\begin{array}{l}W_{m}=\frac{\frac{2 P_{E C . \Sigma}}{\chi}-P_{1}-P_{2}}{2} \cdot \Delta T ; \\ W_{e x}=0\end{array}\right.$

3) $P_{1}>\frac{P_{E C . \Sigma}}{\chi}, P_{2}<\frac{P_{E C . \Sigma}}{\chi},\left\{\begin{array}{l}W_{e x}=\frac{\left(P_{1}-\frac{P_{E C . \Sigma}}{\chi}\right)^{2}}{2\left(P_{1}-P_{2}\right)} \cdot \Delta T \\ W_{m}=\frac{\left(P_{2}-\frac{P_{E C . \Sigma}}{\chi}\right)^{2}}{2\left(P_{1}-P_{2}\right)} \cdot \Delta T\end{array}\right.$

4) $P_{1}<\frac{P_{E C . \Sigma}}{\chi}, P_{2}>\frac{P_{E C . \Sigma}}{\chi},\left\{\begin{array}{l}W_{e x}=\frac{\left(P_{2}-\frac{P_{E C . \Sigma}}{\chi}\right)^{2}}{2\left(P_{2}-P_{1}\right)} \cdot \Delta T \\ W_{m}=\frac{\left(P_{1}-\frac{P_{E C . \Sigma}}{\chi}\right)^{2}}{2\left(P_{2}-P_{1}\right)} \cdot \Delta T\end{array}\right.$

Figure 4 illustrates the four options considered.

Thus, in the time interval $\left[t_{i}, t_{i+1}\right] \quad i=0,1,2 \ldots m$, the value of power, excess $\Delta W_{i} \geq 0$ or absent $\Delta W_{i}<0$ one, according to dependencies (12) - (15), is equal to:

$$
\Delta W_{i}=W_{e x}-W_{m},
$$

where $\mathrm{i}$ is the sequence number of time segment.

If $\Delta W_{i} \geq 0$, some of the excess energy $\Delta \Theta_{a} \cdot \Delta T_{i}$ can be accumulated:

$$
\Delta \Theta_{a i}=\Theta_{a i}-\Theta_{a i}^{e n},
$$

and the rest is uploaded to the system.

Energy balance of the system is described by the following relation:

$$
\Delta \Theta_{a i} \cdot U_{a}+P_{E P S . i} \cdot \Delta T=\Delta W_{i},
$$

where $\Theta_{a i}, \Theta_{a i}^{\kappa}, P_{E P S . i}$ are determined from equations (3) - (6) taking into account the following equations:

$$
P_{a}=\frac{\Delta W_{i}}{\Delta T}, \quad P_{E P S . i}=P_{E P S}, \quad \Delta T=t .
$$

If $\Delta W_{i}<0$, the rest of the energy $\Delta \Theta_{a} \cdot \Delta T_{i}$ must be filled from accumulation system. The equation of energy balance of the system in this case is:

$$
\frac{\Delta W_{i}}{\Delta T}=\Delta \Theta_{a} \cdot \Delta T_{i},
$$

where $\Theta_{a i}$ can be found from equations (10) taking into account (19).

Relations (18) and (20) represent a mathematical model of an electrotechnical complex using distributed generation sources in the structure of which are accumulation systems. The solution of the modeling problem involves implementation of a sequence of mathematical calculations according to the developed methodology for $m$ time points $t_{1}, t_{2}, \ldots, t_{m}$, by which the studied interval of time $T$ is broken into intervals $(m-1)$.

Conclusions and suggestions. One of possible algorithms for optimization of the topology of a virtual power plant, formed by individual electrotechnical complexes with energy accumulation devices, by means of structural analysis of systems is considered. As a criterion to evaluate the correct choice of a particular topology of electrical network, the value of "released" power after solidary covering of its own load can be used.

The focus is on the problem of optimal redistribution of accumulated energy, that is, essentially, on the rationalization of the "charge - discharge" cycle of accumulators.

The relations (18) and (20), representing mathematical model of electrotechnical complex with the use of distributed generation sources and energy accumulators in the form of accumulation systems, are obtained. The solution of the modeling problem involves the implementation of a sequence of mathematical calculations according to the developed methodology for $m$ time points $t_{1}, t_{2}, \ldots, t_{m}$, by which the studied time interval $T$ is broken into intervals $(m-1)$. The completeness of the solutions depends on specific characteristics of the components of the virtual power plant. 


\section{References:}

1. Stohnii, B.S., Kyrylenko, O.V., \& Denysiuk, S.P. (2012). Rozvytok intelektualnykh elektrychnykh merezh na osnovi polozhen kontseptsii SMART GRID [Development of smart grids based on the provisions of the SMART GRID concept]. Institute of Electrodynamics, NAS of Ukraine, pp. 5-13.

2. Othman, M.M., Hegazy, Y.G., \& Abdelaziz, A.Y. (2015). A review of virtual power plant definitions, components, framework and optimization. International Electrical Engineering Journal, vol. 6, no. 9, pp. 2010-2024.

3. Fedorov, V.N. Virtual Power Plant (VPP) as a mechanism for improving network power efficiency. Moscow: Rosseti. Available at: https://docplayer.com/31882461-Virtual-power-plant-vpp-kak-mehanizm-povysheniyaeffektivnosti-ispolzovaniya-setevoy-moshchnosti.html (accessed: 03.02.2020).

4. Denysiuk, S.P., \& Horenko D.S. (2016). Analiz problem vprovadzhennia virtualnykh elektrostantsii [Analysis of virtual power plant implementation problems]. Enerhetyka: ekonomika, tekhnolohii, ekolohiia, no. 2, pp. 25-33.

5. Derevianko, D.H., \& Horenko, D.S. (2016). Osoblyvosti pobudovy ta funktsionuvannia virtualnykh elektrostantsii v umovakh rozvytku OES Ukrainy [Peculiarities of construction and operation of virtual power plants in the conditions of development of Ukrainian UES]. Enerhetyka: ekonomika, tekhnolohii, ekolohiia, no. 3, pp. 61-69.

6. Barybin, Yu.G. et al. (Eds.). (1990). Spravochnik po proektirovaniyu elektrosnabzheniya [Reference book on power supply design]. Moscow: Energoizdat.

7. Voropay, N.I. (2000). Teoriya sistem dlya elektroenergetikov: uchebnoe posobie [The theory of systems for electric power: textbook]. Novosibirsk: Nauka, Sib. izd. firma RAN.

8. Harari, F. (1973). Teoriya grafov [Theory of graphs]. Moscow: Mir.

\section{Список літератури:}

1. Стогній Б.С., Кириленко О.В., Денисюк С.П. Розвиток інтелектуальних електричних мереж на основі положень концепції SMART GRID. Інститут електродинаміки НAH України. 2012. С. 5-13.

2. Othman, M.M., Hegazy Y.G., Abdelaziz A.Y. A review of virtual power plant definitions, components, framework and optimization. International Electrical Engineering Journal. 2015. Vol. 6, no. 9. P. 2010-2024.

3. Федоров B.H. Virtual Power Plant (VPP) как механизм повышения әфффективности использования сетевой мощности. Москва: Россети. URL: https://docplayer.ru/31882461-Virtual-power-plant-vpp-kak-mehanizmpovysheniya-effektivnosti-ispolzovaniya-setevoy-moshchnosti.html (дата звернення: 02.03.2020).

4. Денисюк С.П., Горенко Д.С. Аналіз проблем впровадження віртуальних електростанцій. Енергетика: еконоліка, технологї̈, екологія. 2016. № 2. С. 25-33.

5. Дерев'янко Д.Г., Горенко Д.С. Особливості побудови та фрункціонування віртуальних електростанцій в умовах розвитку ОЕС України. Енергетика: еконоліка, технологї, екологія. 2016. № 3. С. 61-69.

6. Справочник по проектированию электроснабжения / под ред. Ю.Г. Барыбина и др. Москва : Энергоиздат, 1990.

7. Воропай Н.И. Теория систем для электроэнергетиков : учеб. пособие. Новосибирск : Наука, Сиб. изд. фирма PAH, 2000.

8. Харари Ф. Теория графов. Москва : Мир, 1973. 